\title{
Article \\ Amyloid Structural Changes Studied by Infrared Microspectroscopy in Bigenic Cellular Models of Alzheimer's Disease
}

\author{
Agnes Paulus 1,2, Anders Engdahl ${ }^{1}$ (D), Yiyi Yang ${ }^{2}$, Antonio Boza-Serrano ${ }^{2}$, Sara Bachiller ${ }^{2}$,

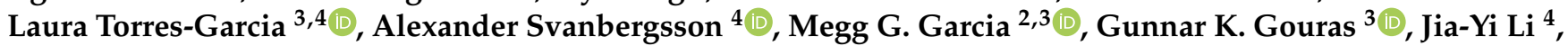 \\ Tomas Deierborg ${ }^{2, *}$ and Oxana Klementieva ${ }^{1,5, *(D)}$
}

\section{check for} updates

Citation: Paulus, A.; Engdahl, A.; Yang, Y.; Boza-Serrano, A.; Bachiller, S.; Torres-Garcia, L.; Svanbergsson, A.; Garcia, M.G.; Gouras, G.K.; Li, J.-Y.; et al. Amyloid Structural Changes Studied by Infrared Microspectroscopy in Bigenic Cellular Models of Alzheimer's Disease. Int. J. Mol. Sci. 2021, 22, 3430. https:// doi.org/10.3390/ijms22073430

Academic Editor: Vytautas Smirnovas

Received: 26 February 2021

Accepted: 22 March 2021

Published: 26 March 2021

Publisher's Note: MDPI stays neutral with regard to jurisdictional claims in published maps and institutional affiliations.

Copyright: (c) 2021 by the authors. Licensee MDPI, Basel, Switzerland. This article is an open access article distributed under the terms and conditions of the Creative Commons Attribution (CC BY) license (https:/ / creativecommons.org/licenses/by/ $4.0 /)$.
1 Medical Microspectroscopy Laboratory, Department of Experimental Medical Science, Lund University, 22184 Lund, Sweden; agnieszka_agnes.paulus@med.lu.se (A.P.); anders.engdahl@med.lu.se (A.E.)

2 Experimental Neuroinflammation Laboratory, Department of Experimental Medical Science, Lund University, 22184 Lund, Sweden; yiyi.yang@med.lu.se (Y.Y.); antonio.boza_serrano@med.lu.se (A.B.-S.); sara.bachiller@med.lu.se (S.B.); megg.garcia@med.lu.se (M.G.G.)

3 Experimental Dementia Research Unit, Department of Experimental Medical Science, Lund University, 22184 Lund, Sweden; laura.torres-garcia@med.lu.se (L.T.-G.); gunnar.gouras@med.lu.se (G.K.G.)

4 Neural Plasticity and Repair Unit, Department of Experimental Medical Science, Lund University, 22184 Lund, Sweden; alexander.svanbergsson@med.lu.se (A.S.); jia-yi.li@med.lu.se (J.-Y.L.)

5 Lund Institute for Advanced Neutron and X-ray Science (LINXS), 22370 Lund, Sweden

* Correspondence: tomas.deierborg@med.lu.se (T.D.); oxana.klementieva@med.lu.se (O.K.)

\begin{abstract}
Alzheimer's disease affects millions of lives worldwide. This terminal disease is characterized by the formation of amyloid aggregates, so-called amyloid oligomers. These oligomers are composed of $\beta$-sheet structures, which are believed to be neurotoxic. However, the actual secondary structure that contributes most to neurotoxicity remains unknown. This lack of knowledge is due to the challenging nature of characterizing the secondary structure of amyloids in cells. To overcome this and investigate the molecular changes in proteins directly in cells, we used synchrotron-based infrared microspectroscopy, a label-free and non-destructive technique available for in situ molecular imaging, to detect structural changes in proteins and lipids. Specifically, we evaluated the formation of $\beta$-sheet structures in different monogenic and bigenic cellular models of Alzheimer's disease that we generated for this study. We report on the possibility to discern different amyloid signatures directly in cells using infrared microspectroscopy and demonstrate that bigenic (amyloid- $\beta$, $\alpha$-synuclein) and (amyloid- $\beta$, Tau) neuron-like cells display changes in $\beta$-sheet load. Altogether, our findings support the notion that different molecular mechanisms of amyloid aggregation, as opposed to a common mechanism, are triggered by the specific cellular environment and, therefore, that various mechanisms lead to the development of Alzheimer's disease.
\end{abstract}

Keywords: FTIR; amyloid- $\beta$; Tau; $\alpha$-synuclein $\beta$-sheet; cellular environment; Alzheimer's disease

\section{Introduction}

Despite extensive, decades-long research on Alzheimer's disease (AD), there is still no effective treatment to prevent or stop this neurodegenerative disorder. AD is typically characterized by a build-up of aggregated proteins, including amyloid- $\beta(A \beta)$, Tau, and alpha-synuclein ( $\alpha$ Syn), that have a complex interactions in the brain with, for example, lipids [1-4]. The majority of AD cases typically involve more than two neuropathologies, [5] and the co-existence of aggregated $\mathrm{A} \beta, \alpha$ Syn, and Tau has been associated with more rapid cognitive decline [6-10]. The widely accepted amyloid hypothesis [9-12] posits that $A \beta$ is a critical trigger of $\mathrm{AD}$ [11]. Therefore, the development of anti-amyloid drugs that target $\mathrm{A} \beta$ plaques to reduce $\mathrm{A} \beta$ load has been the focus. However, the failure of clinical trials targeting $A \beta$ [12], although recent reports of an immunotherapy using aducanumab have 
been encouraging [13], indicates that the mechanisms of $A \beta$ neurotoxicity are more complex than previously thought [14], and further research is needed to understand the specific role of $A \beta$ and its various molecular species in the pathogenesis of AD. Powerful imaging techniques, such as magnetic resonance imaging and positron emission tomography, have been successfully used to detect the presence of fibrillary amyloids and, in some cases, of oligomeric species extracellularly [15-17], other methods are needed to detect intracellular amyloid and characterize the structure of these aggregates [18].

It has been suggested that amyloid proteins such as $A \beta$ and $\alpha$ Syn can form oligomerssupramolecular structures consisting of several noncovalent assemblies [19] and characterized by structural diversity [20] due to the partial enrichment of $\beta$-sheet structures, which may define the neurotoxicity of oligomers [21]. Still, the relative contribution of amyloid-specific secondary structures to neurotoxicity remains unknown. Conformationspecific antibodies [22] can detect amyloid aggregates but do not help with characterizing the $\beta$-sheet structural content, which may vary between tissues [23,24] and cells [25]. Here, we evaluate the $\beta$-sheet structural content of amyloids in biological samples using Fourier Transform Infrared microspectroscopy ( $\mu$-FTIR) [26-28]. There are three main advantages of using FTIR to study the molecular structure of amyloids: (1) $\mu$-FTIR is sensitive enough to detect $\beta$-sheets [29]. (2) $\mu$-FTIR is label-free, and (3) it is a non-destructive technique. $\mu$-FTIR detects infrared absorbance in the mid-IR region $\left(4000-1000 \mathrm{~cm}^{-1}\right)$, corresponding to changes in the vibrational energy state of functional groups characteristic of biological molecules. Importantly, for $\mu$-FTIR, labeling is not required; therefore, all non-volatile structural components that could be affected by or lost during labeling remain in situ and contribute to the resulting infrared spectrum [30]. $\mu$-FTIR is a sensitive technique that allows spectra acquisition from sample quantities as low as $0.1 \mathrm{ng}$ [31]. Additionally, it is important to mention that infrared energy is too low $(0.05-0.5 \mathrm{eV})$ to break chemical bonds [32]. Here, we analyzed absorbance intensities corresponding to the bands Amide I $\left(1800-1600 \mathrm{~cm}^{-1}\right)$ and Amide II $\left(1570-1470 \mathrm{~cm}^{-1}\right)$ in the infrared spectrum to characterize the main components of amyloids and to reveal the secondary structure of proteins via carbonyl $(\mathrm{C}=\mathrm{O})$ stretching vibrations in the peptide bonds, allowing for the specific detection of $\beta$-sheets and random coil structures [26].

The absorption associated with the Amide I band originates from stretching vibrations of the $\mathrm{C}=\mathrm{O}$ of the amide group. The infrared absorption associated with the Amide II band originates from bending vibrations of $\mathrm{N}-\mathrm{H}$ bonds. Early empirical frequency-structure studies found that $\beta$-sheets have absorption bands at $1640-1610 \mathrm{~cm}^{-1}$ and $1695-1680 \mathrm{~cm}^{-1}$; random coil and $\alpha$-helix structures are located in the ranges of $1650-1637$ and $1660-1650 \mathrm{~cm}^{-1}$ [33-37].

More recent studies have found that the principal components of amyloid- $\beta$ aggregates can be detected as absorbance at $1628 \mathrm{~cm}^{-1}$ and that the aggregates are characterized by intra- and inter-molecular $\beta$-sheet structural content $\left(1985\right.$ and $\left.1691 \mathrm{~cm}^{-1}\right)[37,38]$. It has also been suggested that amyloid oligomers can be partially unordered (increased content of random coils). Thus, the absorbance peak at $1637 \mathrm{~cm}^{-1}$ can be used for further protein structure characterization as a ratio between the unordered structure band at $1637 \mathrm{~cm}^{-1}$ and Amide I $\left(1656 \mathrm{~cm}^{-1}\right)$ [39]. As a measure of protein folding, we used the Amide II/Amide I ratio; to measure cell damage, we monitored for lipid oxidation, defined as absorption at $1740 \mathrm{~cm}^{-1}$ by the carbonyl group of the ester bond in the infrared spectrum [40].

This work aimed to study the structural changes of amyloid aggregation in cultured neuron-like mouse cells stably overexpressing human amyloid precursor protein (APP) with the Swedish mutation (N2aAPPSWE) [41], this mutation is commonly used in models of $\mathrm{AD}$ because it strongly enhances overall $\mathrm{A} \beta$ production [42,43]. To understand better interaction of $A \beta, \alpha$ Syn and Tau within a cell, we produced bigenic cells overexpressing (1) $\mathrm{APP}_{\text {SWE }}$ and $\alpha$ Syn, (2) APP SWE and Tau. Using immunofluorecence labeling we assessed fibrilization of $A \beta$; using infrared spectroscopy we characterized structural changes directly in neuron-like cells simultaneously expressing human $A \beta$ and $\alpha$ Syn, $A \beta$ and Tau. Obtaining new information about AD-related structural changes in proteins is an important step 
in understanding the molecular mechanisms behind $\mathrm{AD}$; these results could also provide insight into the pathology of other amyloidogenic diseases.

\section{Results}

\section{1. $\alpha$ Syn and Tau Affect the Quality of Intracellular A Aggregates}

To study AD protein aggregation, we used a mouse neuroblastoma (N2a) cell line that was stably transfected with human APP harboring the Swedish mutation (N2a-APP ${ }_{S W E}$ ). N2a-APP ${ }_{S W E}$ cells overexpress $A \beta(1-42)$, which can then form intracellular $\beta$-sheet rich aggregates [41]. To study the effect of human $\alpha$ Syn and Tau on $A \beta$ aggregation, we generated additional cellular models, wherein human $\alpha$ Syn or Tau were expressed together with APP SWE. To that end, N2a-APP $_{\text {SWE }}$ cells were transfected with plasmids encoding for either $\alpha$ Syn or Tau coupled to GFP (Supplementary Figure S1). In all cell models, A $\beta$ expression was analyzed by immunolabeling, using the A $\beta$-specific antibody 82E1 [44] and the amyloid fibril-specific antibody OC78 [45] (Figure 1). We did not observe any significant changes in $A \beta$ expression levels between cell lines (Figure 1A); however, an analysis of the signal distribution showed a two-fold decrease in the size of $A \beta$ aggregates in the presence of Tau or $\alpha$ Syn (Figure 1B). Our results also revealed that the A $\beta$ co-aggregation level (OC and 82E1), calculated as co-localization with $A \beta-\alpha$ Syn or $A \beta$-Tau using the Pearson's coefficient, was significantly decreased (22\%) in the presence of co-expressed $\alpha \mathrm{Syn}$, in N2a-APP SWE $^{-} \alpha$ Syn cells $(p=0.016$ ) (Figure 1C). These results indicate that $\alpha$ Syn's presence affects the structure and morphology of $\mathrm{A} \beta$ aggregates.

\section{2. $\alpha$ Syn Reduces $\beta$-Sheet Load in a Bigenic A $\beta / \alpha$ Syn Cellular Model}

To further study protein aggregation in the presence of co-expressed human $A \beta$, $\alpha$ Syn, and Tau, we used synchrotron-based Fourier Transform Infrared microspectroscopy ( $\mu$ FTIR). Historically, $\mu$ FTIR cell studies have been conducted using synchrotron radiation sources due to high brightness that allow the use of a smaller aperture for the synchrotron measurement $\left(6 \mu \mathrm{m}^{2}\right.$ compared to the $20 \mu \mathrm{m}^{2}$ available in the laboratory sources) [30,46]. Using $\mu$ FTIR we studied subtle structural changes directly in the individual cells grown on the $\mu$ FTIR sample support surface. Specifically, we monitored wavenumbers corresponding to several characteristics of interest: (1) major component characteristics for $\beta$-sheet structures $\left(1628 \mathrm{~cm}^{-1}\right)$ together with a minor component of the $\beta$-strands $\left(1691 \mathrm{~cm}^{-1}\right)$; (2) random coils $\left(1637 \mathrm{~cm}^{-1}\right)$; and (3) the relative intensity of Amide II $\left(1557 \mathrm{~cm}^{-1}\right)$ (Tables 1 and 2).

Table 1. Summary of peak positions used in the study.

\begin{tabular}{cc}
\hline Wavenumbers $\left(\mathbf{c m}^{-\mathbf{1}}\right)$ & Structure \\
\hline $1656 \mathrm{~cm}^{-1}$ & $\mathrm{C}=\mathrm{O}$ stretching, Amide I \\
$1550 \mathrm{~cm}^{-1}$ & $\mathrm{C}-\mathrm{N}$ stretching; $\mathrm{N}-\mathrm{H}$ bending, Amide II \\
$1628 \mathrm{~cm}^{-1}$ & $\beta$-sheet (main) \\
$1640 \mathrm{~cm}^{-1}$ & random coils (unordered) \\
$1656 \mathrm{~cm}^{-1}$ & $\alpha$-helix \\
$1691 \mathrm{~cm}^{-1}$ & $\beta$-sheet (weak) \\
$1740 \mathrm{~cm}^{-1}$ & $\mathrm{C}=\mathrm{O}$ bond of the ester peak \\
\hline
\end{tabular}

Table 2. Summary of bands ratios used for infrared spectra analysis.

\begin{tabular}{cc}
\hline Ratio & Structure \\
\hline $1550 \mathrm{~cm}^{-1} / 1656 \mathrm{~cm}^{-1}$ & protein folding \\
$1628 \mathrm{~cm}^{-1} / 1656 \mathrm{~cm}^{-1}$ & parallel $\beta$-sheet features \\
$1640 \mathrm{~cm}^{-1} / 1656 \mathrm{~cm}^{-1}$ & random coils (unordered) \\
$1691 \mathrm{~cm}^{-1} / 1628 \mathrm{~cm}^{-1}$ & anti-parallel $\beta$-sheet \\
$1740 \mathrm{~cm}^{-1} / 1656 \mathrm{~cm}^{-1}$ & $\mathrm{C}=\mathrm{O}$, lipid oxidation \\
\hline
\end{tabular}


A
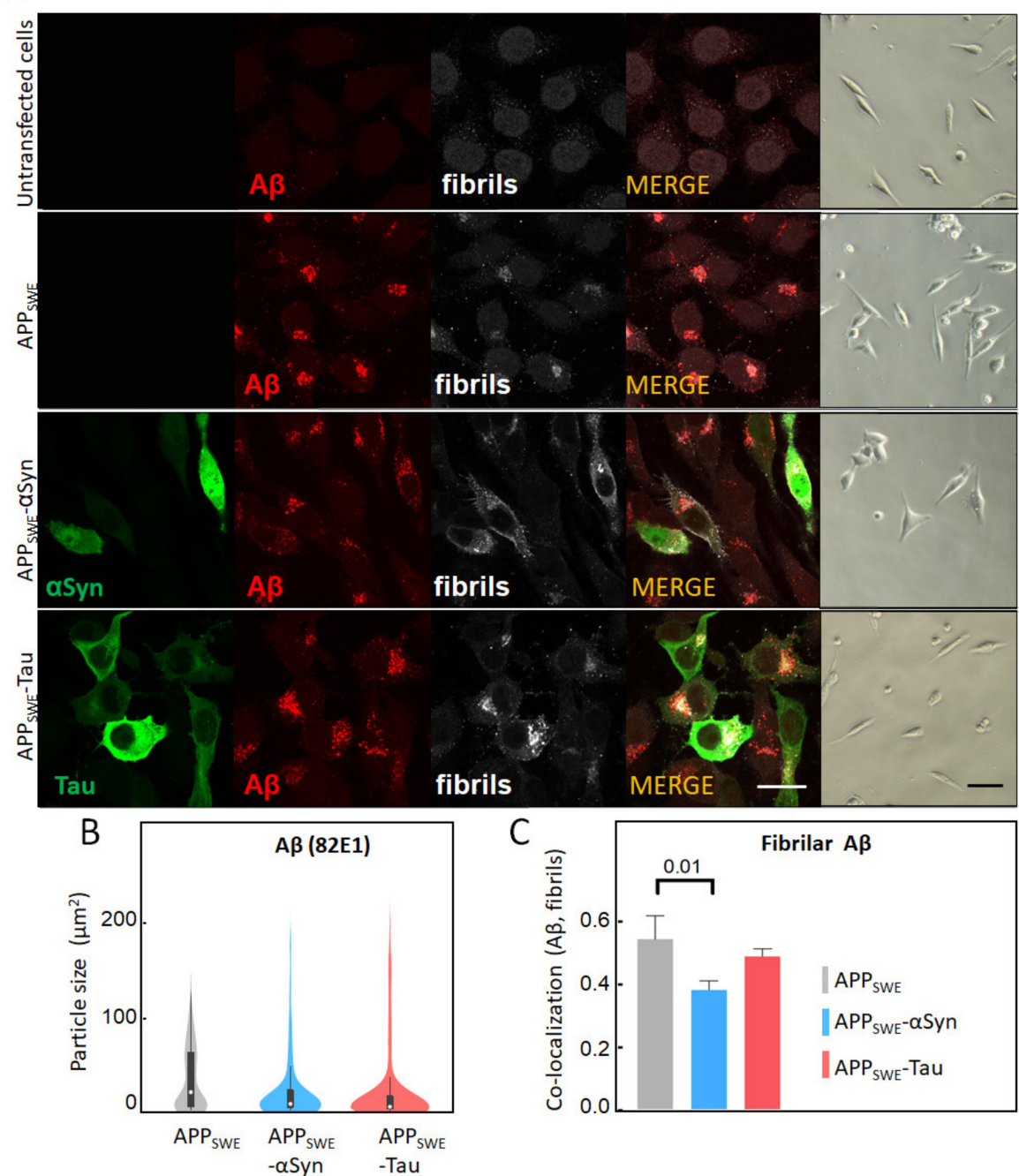

C

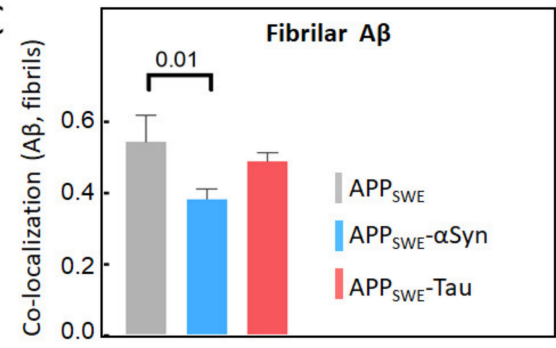

Figure 1. Immunofluorescent characterization of $A \beta$ in cellular models of Alzheimer's disease (AD). (A) Immunofluorescent labeling of $\mathrm{A} \beta$ with 82E1 (red) and amyloid fibrils with OC78 (white). The green fluorescence channel corresponds to mutated Tau (P301L) or $\alpha$ Syn (A53T) coupled to GFP. Bright-field images show the condition of fluorescence-activated cell sorting (FACS)-sorted cells (Supplementary Figures S2-S5). The scale bar is $20 \mu \mathrm{m}$. (B) Quantification of particle size was calculated using surface areas in immunosignal corresponding to $82 \mathrm{E} 1$ immunoreactivity. Aggregated A $\beta$ was computed by co-localization analysis of $\mathrm{A} \beta$ (82E1) and amyloid fibrils (OC78). A threshold was set at $5 \%$ of max size (Supplementary Figure S6). (C) Statistical analysis of the co-localization of A $\beta$ with fibrillary A $\beta$ : one-way ANOVA $(p<0.01) \pm \mathrm{s} . \mathrm{d} ; n=25-35$ cells per sample. A coefficient of 1 is equal to $100 \%$ co-localization.

First, we studied the effect of mutated $\alpha$ Syn (A53T) on A $\beta$ aggregation (Figure 2). The A53T mutation promotes the formation of $\alpha$ Syn fibrils in vitro, leading to a Parkinson's disease-like pathology [47]. Our data showed that the presence of A $\beta$ and $\alpha$ Syn in N2a$\mathrm{APP}_{\mathrm{SWE}^{-}} \alpha \mathrm{Syn}$ cells led to a significantly reduced level of $\beta$-sheet structures compared

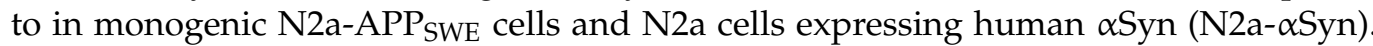
This decrease was accompanied by a significant reduction in random coils (unordered) structures and changes in total protein folding (Figure 2B), indicating a possible reduction in aggregate toxicity via reduced protein folding. We observed an effect of GFP on $\beta$-sheet structures (Figure 2C); therefore, to consider the contribution of GFP in the structural analysis, N2a-APP ${ }_{\text {SWE }}$ cells transfected with GFP only (APPSWE) were used as a control. 

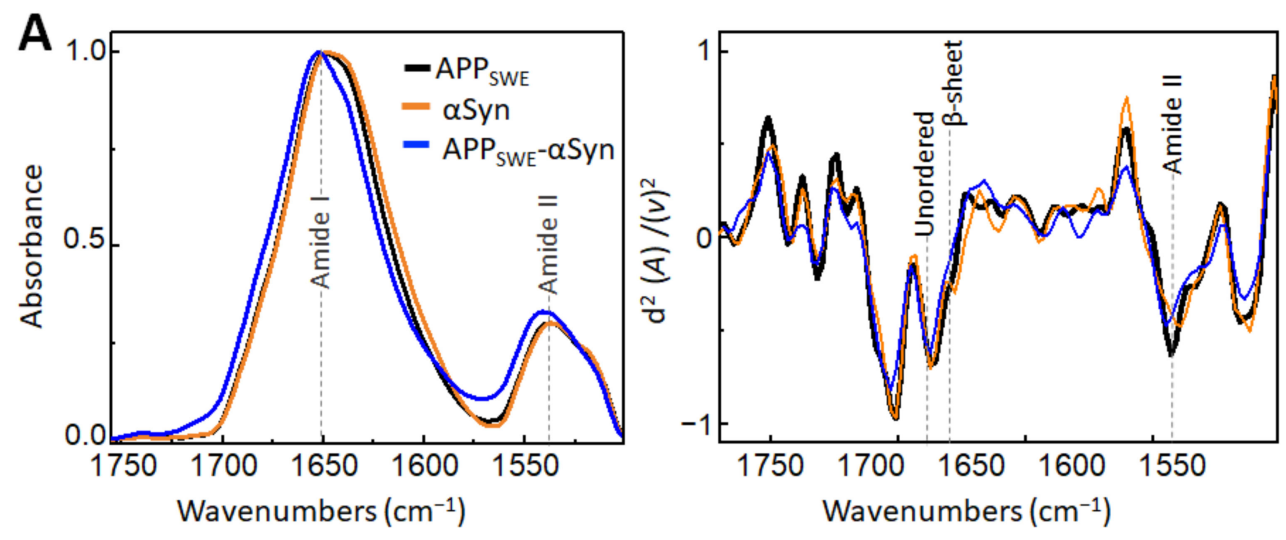

B $\beta$-sheet structures
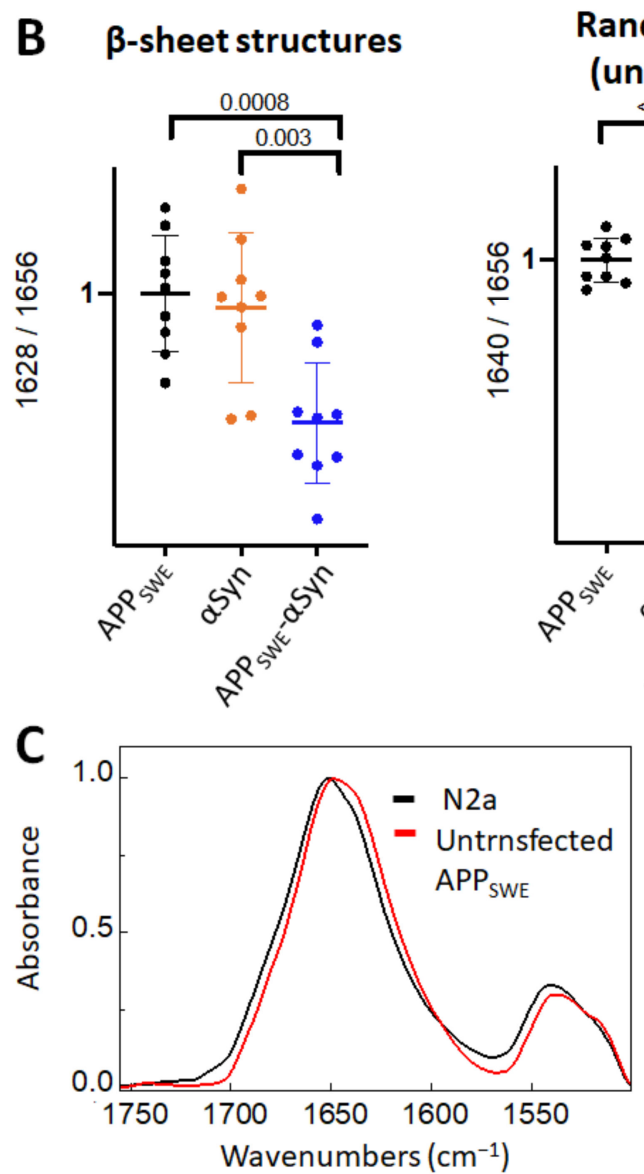

Random coils

(unordered)

$<0.0001$

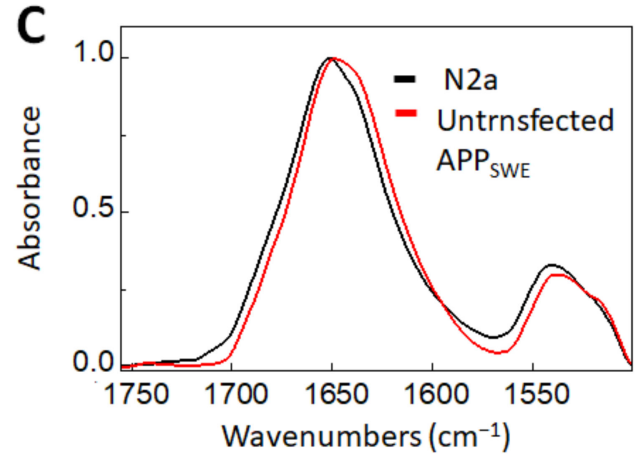

Protein folding

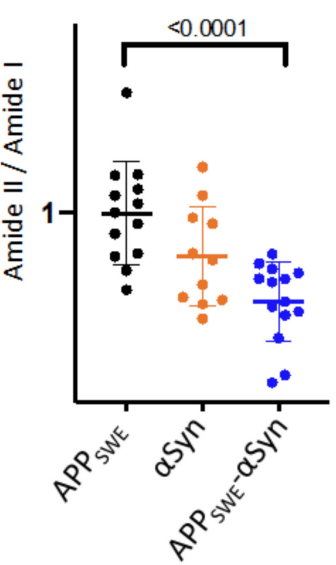

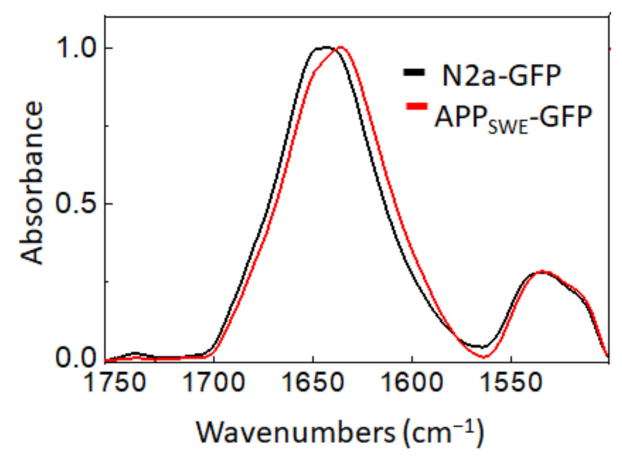

Figure 2. Effect of $\alpha$ Syn (A53T) on A $\beta$ aggregation in A $\beta / \alpha$ Syn cellular model of AD. (A) Averaged and normalized infrared absorbance spectra and corresponding normalized second derivatives of N2a-APPSWE, N2a- $\alpha$ Syn, N2a-APP $\mathrm{SWE}^{-} \alpha \mathrm{Syn}_{\mathrm{S}}$. Dashed lines indicate peak positions. (B) Statistical analysis of structural changes. One-way ANOVA $(p<0.01) \pm$ s.d; one dot corresponds to a single cell; $n=7-20$ cells per independent measurement reproduced at least twice. All values are normalized to the control-N2a-APP $\mathrm{SWE}_{\mathrm{N}}$ cells. (C) Averaged and normalized infrared absorbance spectra of N2a-APP $\mathrm{SWE}$ and N2a cells untransfected (left panel) and transfected with GFP (right panel).

\subsection{A $\beta$ Reduces the Level of $\beta$-Sheet Aggregates in the Bigenic A $\beta / T a u$ Cellular Model}

As a next step, we studied $A \beta$ aggregation in the presence of Tau containing the P301L mutation (Figure 3). Immunofluorescence data (Figure 1C) combined with FTIR analysis showed that the presence of Tau reduced the average size of $A \beta$ aggregates without a significant change to the $\beta$-sheet structural load (Figure 3B). Interestingly, in N2a cells expressing Tau alone (N2a-Tau), the levels of $\beta$-sheet load, random coils structures, and 
lipid oxidation were significantly increased compared to A $\beta$-expressing cells (N2a-APP ${ }_{S W E}$ and N2a-APP ${ }_{\text {SWE-Tau cells). }}$
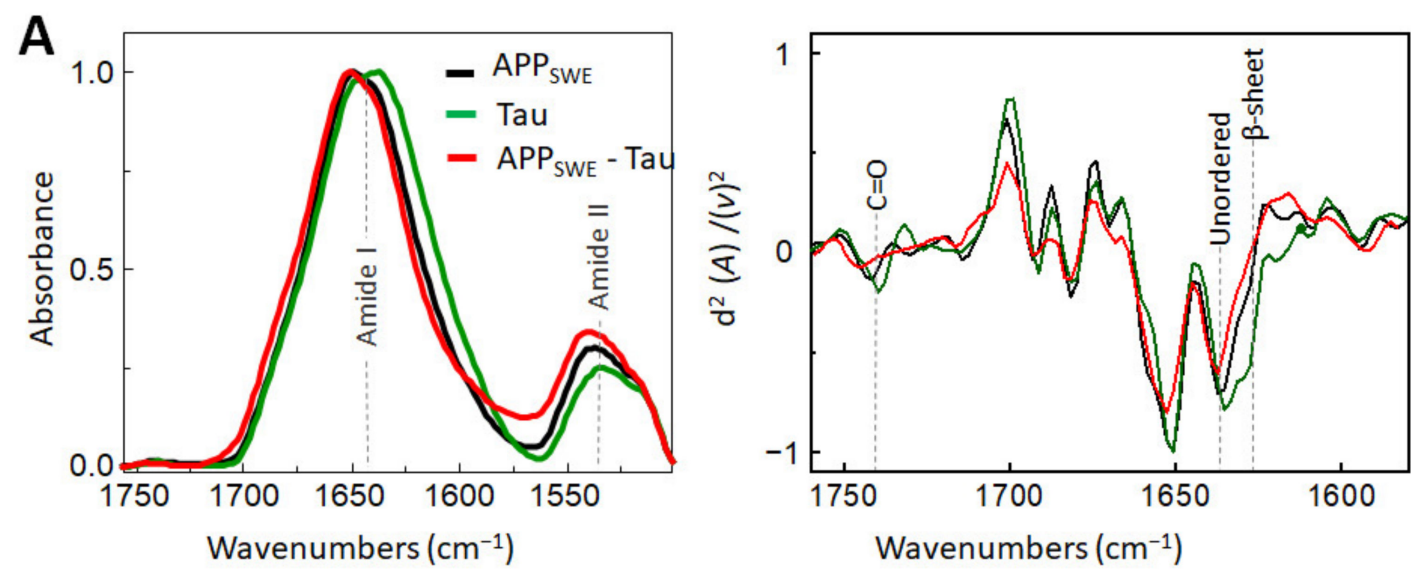
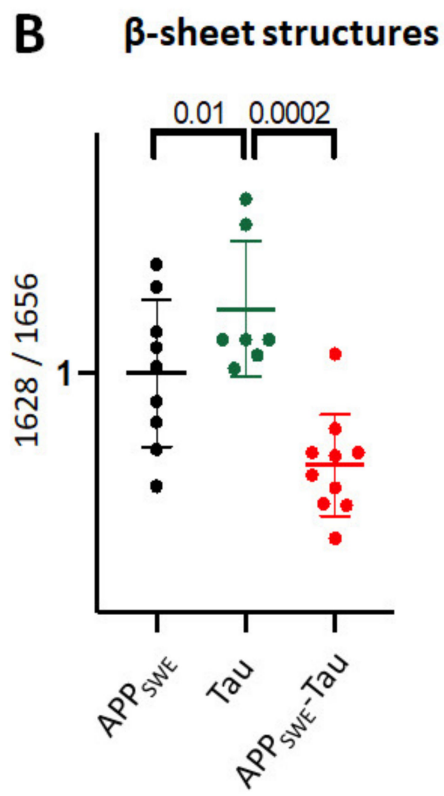

Random coils (unordered)

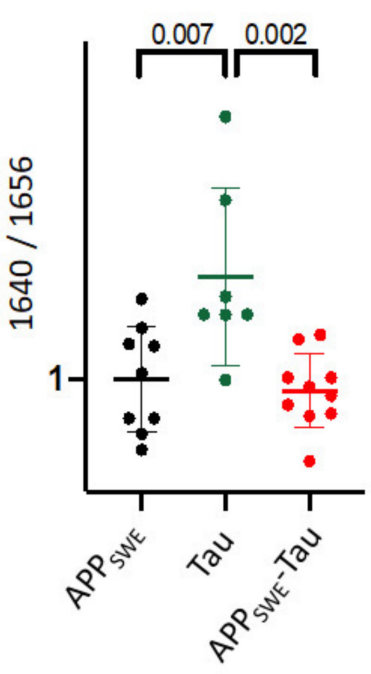

Lipid oxidation

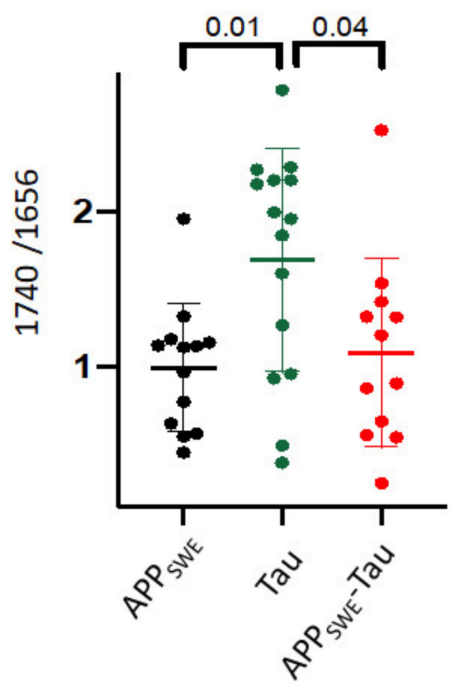

Figure 3. Effect of Tau (P301L) on A $\beta$ aggregation in A $\beta$ /Tau cellular model of AD. (A) Averaged and normalized infrared absorbance spectra and corresponding normalized second derivatives of N2a-APPSWE, N2a-Tau, N2a-APPSWE-Tau. Dashed lines indicate peak positions (B) Statistical analysis of structural changes. One-way ANOVA $(p<0.01) \pm$ s.d; one dot corresponds to a single cell, $n=7-20$ cells per independent measurement, reproduced at least twice. All values were normalized to the control-N2a-APPSWE cells.

\subsection{Diverging Patterns of Amyloid Aggregation in Monogenic and Bigenic Cellular Models}

When comparing monogenic cellular models of amyloid aggregation (Figure 4), we observed that the anti-parallel $\beta$-sheet load was significantly lower in cells that expressed

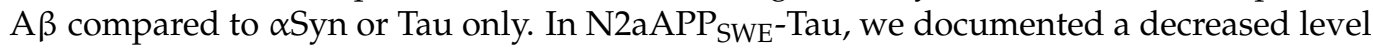
of Amide II absorbance (Figure 4A) and increased level of lipid oxidation (Figure 4B), that was significantly different from cells expressing only $A \beta$. 


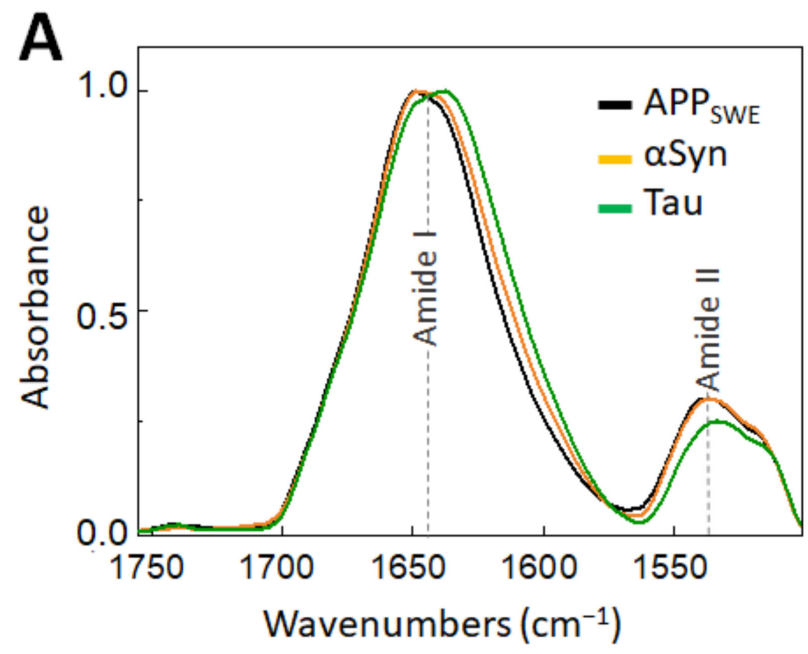

B
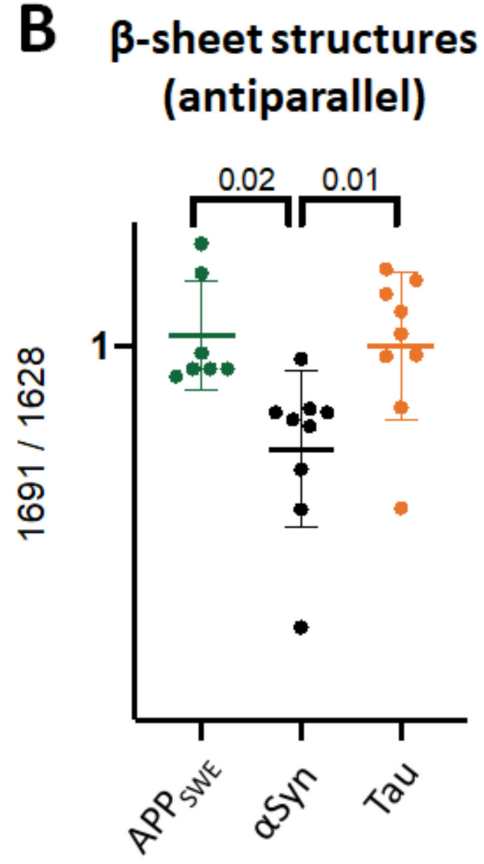

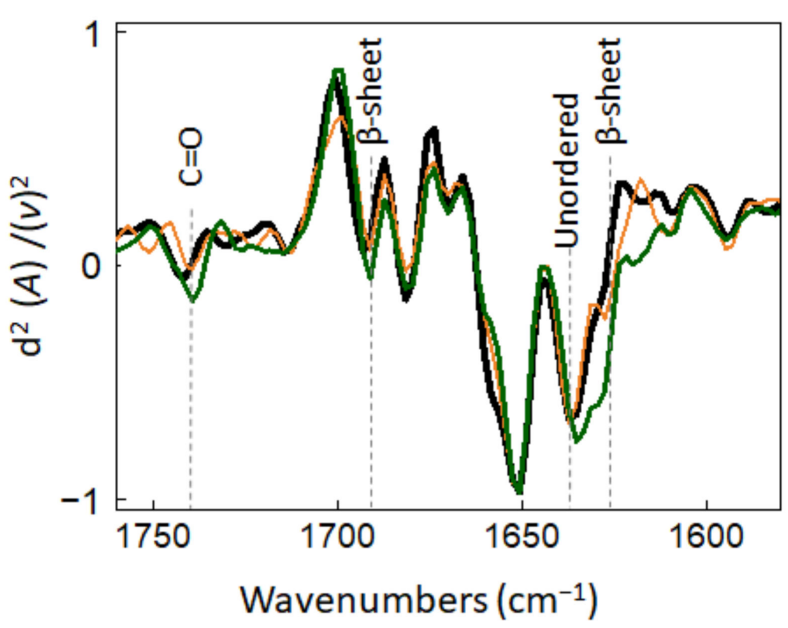

Lipid oxidation

Random coils (unordered)

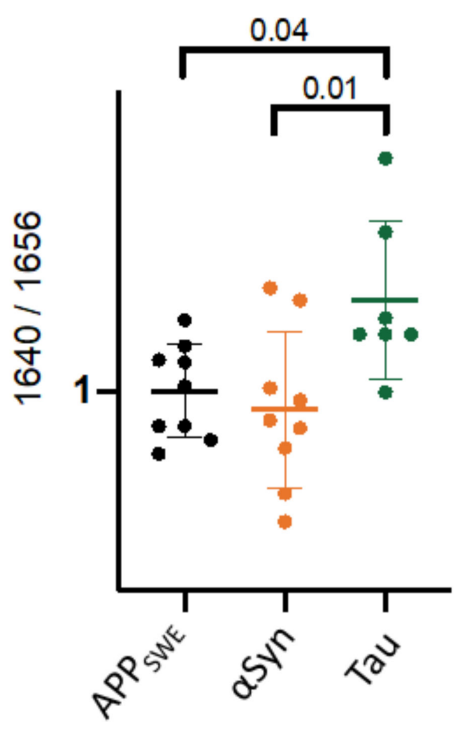

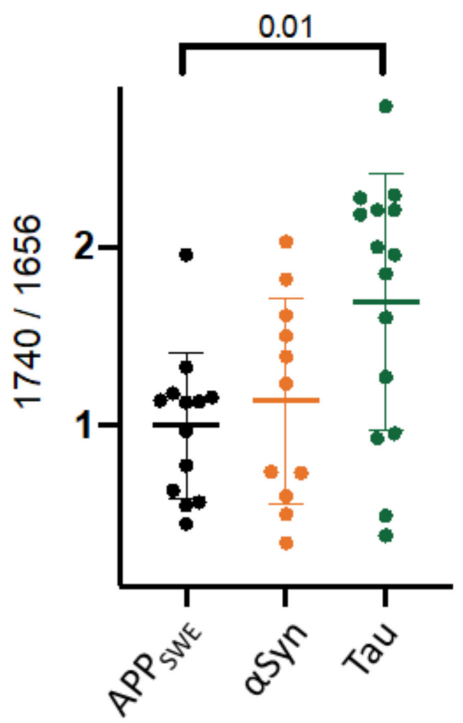

Figure 4. Comparison of structural changes in protein aggregates in the monogenic models of protein aggregation related to AD. (A) Averaged and normalized infrared absorbance spectra and corresponding normalized second derivatives of

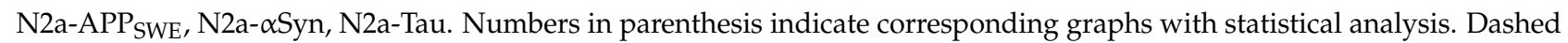
lines indicate peak positions. (B) Statistical analysis of structural changes: one-way ANOVA $(p<0.01) \pm$ s.d. All values were normalized to the control, N2a-APP $\mathrm{SWE}_{\mathrm{N}}$ cells. One dot corresponds to a single cell, $n=7-20$ cells per independent measurement reproduced at least twice.

In the bigenic cellular models of amyloid aggregation (Figure 5), we observed that the total $\beta$-sheet load was significantly decreased, in contrast to the total $\beta$-sheet load in cells that expressed only A $\beta$. This implies that both $\alpha$ Syn and Tau can affect $A \beta$ aggregation. 

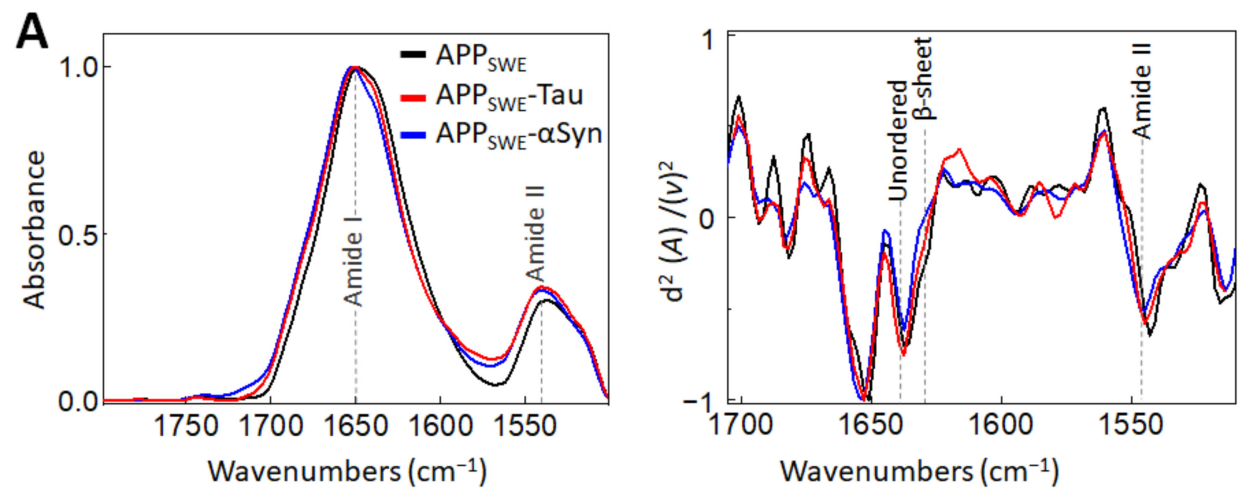

B $\beta$-sheet structures
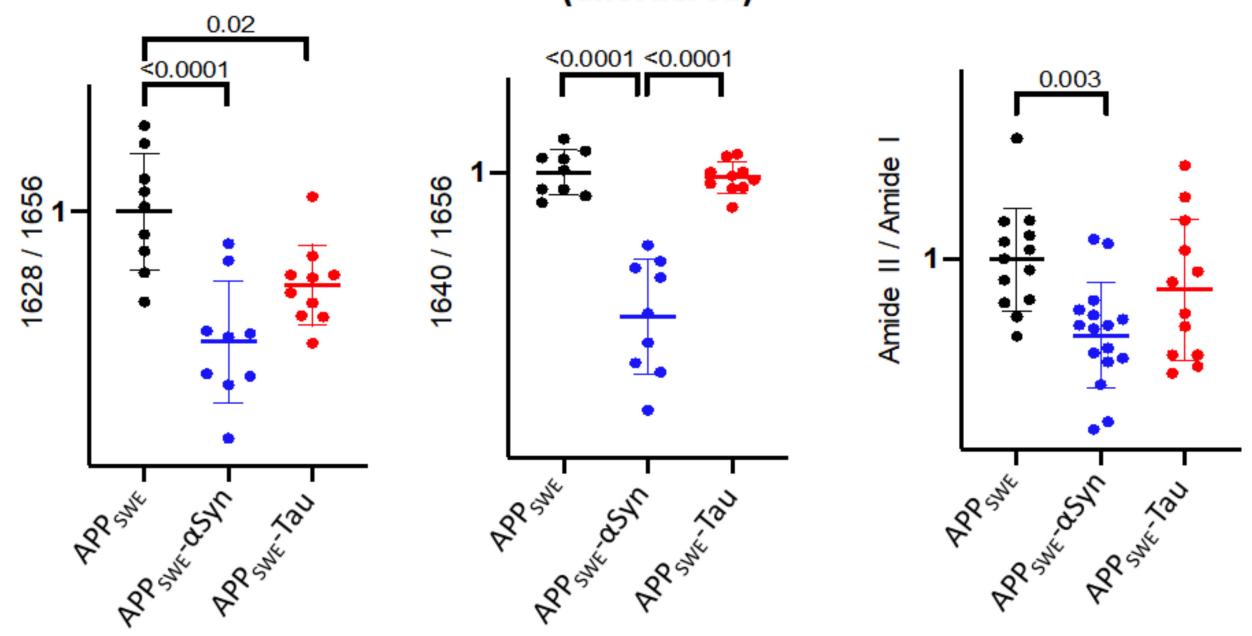

Figure 5. Comparison of structural changes in protein aggregates in the bigenic models of AD protein aggregation. (A) Averaged and normalized infrared absorbance spectra and corresponding normalized second derivatives of N2a-

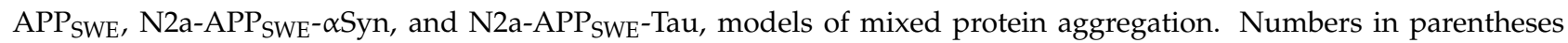
indicate corresponding graphs with statistical analysis. Dashed lines indicate peak positions. (B) Statistical analysis of

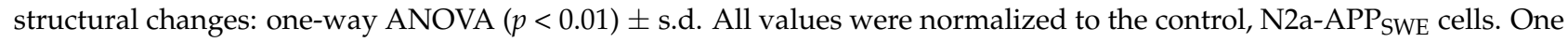
dot corresponds to a single cell, $n=7-20$ cells per independent measurement reproduced at least twice.

\section{Discussion}

Based on our results, we speculate that in human neurons, wherein all three proteins are physiologically present, the formation of amyloid aggregates may involve different folding, aggregation, and post-translational modification processes depending on the cellular environment and pathological conditions.

There is still no consensus on the neurotoxicity of aggregated $A \beta, \alpha$ Syn, and Tau, which hinders progression when targeting these proteins for therapeutic intervention. To understand the molecular mechanisms behind the toxicity of amyloids, it is necessary to elucidate the relationship between structure and neurotoxicity. However, characterizing the structure of these amyloid aggregates is extremely challenging primarily because of their high heterogeneity. Thus, identifying their structure, which may hint at their neurotoxicity, is fundamental in identifying new therapeutic targets. Studies on amyloid aggregates, so-called amyloid oligomers, typically rely on brain tissue processed by various techniques, including homogenization, high-speed centrifugation, and SDS (sodium dodecyl sulfate) gel electrophoresis. However, such procedures can alter protein conformations or states of assembly. Hence, no consensus exists regarding amyloid aggregate structures in the 
brain, their association with $\mathrm{AD}$ pathogenesis, and their respective contribution to the pathogenesis $[14,48]$.

In this study, we used synchrotron-based $\mu$ FTIR [32] to measure $\beta$-sheet structural content, protein folding $[49,50]$, and lipid oxidation in order to determine amyloid toxicity $[30,51]$. $\mu$ FTIR provides simultaneous measurements over the entire wavenumber range, producing broad information about molecular structures [36,37]. Since all molecules are continuously vibrating, almost all molecular bonds absorb infrared energy, and this absorption is measurable by $\mu$ FTIR spectroscopy in situ [36]. The label-free and non-destructive properties of $\mu$ FTIR were crucial for this work due to the high fragility and heterogeneity of amyloid structures in cells [25].

Aggregated $A \beta, \alpha$ Syn, and Tau have been detected in postmortem brain tissue of $\mathrm{AD}$ patients, raising the possibility that these amyloids could interact and generate toxic aggregates $[3,52,53]$. We examined $\mathrm{A} \beta$ aggregation in our monogenic and bigenic cellular models of amyloid aggregation. To understand better interaction of $A \beta, \alpha$ Syn and Tau within a cell, we used neuron-like mouse cells N2a stably overexpressing human APP with the Swedish mutation $\left(\mathrm{APP}_{\mathrm{SWE}}\right)$ [41]. This mutation is immediately adjacent to the $\beta$-secretase site in amyloid precursor protein, resulting in the substitution of two amino acids: lysine and methionine to asparagine and leucine, respectively, that strongly enhances overall A $\beta$ production [42,43]. Historically, $\mu$ FTIR cell studies have been conducted using synchrotron radiation sources due to high brightness of the synchrotron beam [30,51]. Using high brightness of synchrotron sources, it is possible to spectra of analytical grade quality from individual cells which is challenging to achieve by commercially available FTIR microscopes. However, with the recent development of optical photothermal spectroscopy [54], a new benchtop solution is available to study protein structures [25]. Here, we used synchrotron-based $\mu$ FTIR to study molecular structures in neuron-like cells stably in $A \beta / \alpha$ Syn and $A \beta /$ Tau bigenic cells. Thus we produced a cell that co-express (1) A $\beta$ and $\alpha$ Syn with aggregation-prone A53T mutation [52], (2) A $\beta$ and Tau containing the P301L mutation, which promotes neurofibrillary tangle formation [53].

Thus, our findings provide novel evidence that $\alpha$ Syn and $A \beta$ can modulate the structure of $\beta$-sheet aggregates in cellular models. Our study demonstrated that bigenic APP / $\alpha$ Syn neuron-like cells display reduced $\beta$-sheet load and an altered oligomeric A $\beta$ profile. On the other hand, bigenic APP/Tau neuron-like cells display reduced $\beta$-sheet load compared to the monogenic Tau model and an altered oligomeric $A \beta$ profile.

In addition to the uncertainties surrounding the interactions between amyloid oligomers, the contribution of $\alpha$ Syn and Tau to changes in the amyloid load itself remains unresolved in $\mathrm{AD}$ [3]. Additionally, the exact relationship between changes in amyloid oligomer structures and the cellular environment has not been clearly defined [55]. In our immunofluorescence analysis, we unexpectedly noticed that $\alpha$ Syn and Tau affect both the size and quality of intracellular $A \beta$ aggregates. Combining these results with the $\mu$ FTIR data, we observed that expression of $\alpha$ Syn (A53T) in N2a-APPSWE neuron-like cells resulted in a decreased $\beta$-sheet load and that the effect was bidirectional. In contrast, the presence of aggregation-prone Tau did not affect $\beta$-sheet load in N2a-APPSWE cells. Our data are supported by in vivo experiments that showed markedly reduced amyloid deposition in bigenic animals that overexpress human wild-type $\alpha$ Syn and A $\beta$ [56]. Taken together, our data show that bigenetic models that involve $\alpha$ Syn and Tau in conjunction with $A \beta$ can offer new functional insight into $\mathrm{AD}$ development. The current models of amyloid aggregation used in studies represent rare conditions, wherein two mutated proteins are expressed in the cells; however, our combination of monogenic and bigenic models allows one to study bidirectional effects on amyloid protein aggregation. In this study, we looked at amyloid proteins that are known to be physiologically present in human neurons and explored how they can interact and alter each other. Such structural interactions are important to study as they may lead to the formation of more neurotoxic amyloid aggregates. It is also possible that the neurotoxicity seen in AD can be attributed to other factors, such as altered cellular structures or cells that affect neural cells (i.e., microglia are known to be crucial in AD pathogenesis) [57]. Considering the complex effects 
of the interaction between $\alpha \mathrm{Syn}, \mathrm{A} \beta$, and Tau on their aggregation, further development of $\mu$ FTIR is required for fluorescence-guided measurements of the $\beta$-sheet load in different cellular environments. Further studies will help better understand the relationship between amyloid aggregate structure and toxicity. In future studies, it will be important to include other cellular readouts to detect neurotoxicity, including altered electrophysiological properties, such as gamma oscillations [58], and direct/indirect actions by the glial population [59].

In conclusion, our findings suggest that $\alpha$ Syn and Tau contribute to structural changes in A $\beta$ in AD. Furthermore, our study demonstrates that bigenic APP/ $\alpha$ Syn and APP/Tau neuron-like cells display changes in $\beta$-sheet loads along with altered oligomeric $A \beta$ profiles. Thus, our findings support the notion that there are a multitude of molecular mechanisms driving amyloid aggregation (depending on the particular cellular environment and conditions), which will be important to consider when studying and treating proteinopathic neurodegenerative diseases.

\section{Materials and Methods}

\subsection{Plasmids}

$\alpha$ Syn: The lentiviral plasmid encoding $\alpha$ Syn (A53T)-GFP was produced by Gibson assembly using the 2nd generation lentiviral plasmid $\mathrm{pHsCXW}$ as recipient and a previously generated fusion construct of $\alpha$ Syn (A53T)-GFP as a donor. Briefly, the backbone was linearized by restriction enzymes, SgfI (\#FD2094, ThermoFischer Scientific, Gothenburg, Sweden) and MluI (\#FD0564, ThermoFischer Scientific, Gothenburg, Sweden), and the $\alpha$ Syn (A53T)-GFP fusion sequence was amplified using the following primers:

Primer 1: cgttagacgcgatatggatgtattcatgaaaggac; Primer 2: cgagacgcgtgtcacttgtacagctcatccatgc.

Assembly of the construct was performed through one-pot assembly using NEB $2 x$ Gibson assembly master mix (New England Biolabs, NEB-E2611L, Ipswich, MA, USA), following the manufacturer's protocol.

Tau: Similarly, the lentiviral plasmids containing Tau-GFP (P301L) were generated by Gibson Assembly. The pHsCXW backbone was linearized by enzymatic restriction with BamHI (\#FD0054, ThermoFisher Scientific, Gothenburg, Sweden) and SalI (\#FD0644,ThermoFisher Scientific, Gothenburg, Sweden). Tau and GFP sequences were amplified from previously generated constructs with the following primers for Tau:

Primer 3: catagaagacaccgactctagagatggctgagcccegccag; Primer 4: caccaccactaccacccaaaccetgcttggccagg) and with the following primers for GFP amplification:

Primer 5: gcagggtttgggtggtagtggtggtggtagtggtggtatggtgagcaagggcgag;

Primer 6: tagggcgctcgagacgcgtgttacttgtacagctcgtccatg).

Assembly of the fragments was done using NEB 2x Gibson Assembly Master Mix (\#NEB-E2611L, New England Biolabs, Ipswich, MA, USA) following the manufacturer's instructions.

\subsection{Cell Lines}

We used a mouse neuroblastoma cell line (N2a) stably transfected with human amyloid precursor protein harboring the Swedish mutation ( $\mathrm{APP}_{\mathrm{SWE}}$ ), which overexpresses $\mathrm{A} \beta$ and can form intracellular, $\beta$-sheet-rich aggregates [60]. To study the effect of $\alpha$ Syn and Tau on

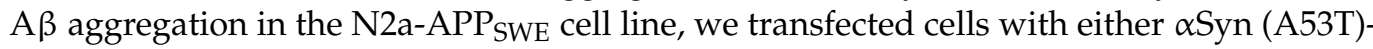
GFP and Tau (P301L)-GFP plasmids. Cells were plated in 10-cm Petri dishes and grown in conditioned media containing $47 \%$ high glucose Dulbecco's modified Eagle's medium (DMEM) (\# SH30243.01, GE Healthcare Life Sciences, Uppsala, Sweden), 47\% Optimem (\#31985-047, ThermoFisher Scientific, Gothenburg, Sweden), 5\% fetal bovine serum (FBS) (\# 10500-064, ThermoFisher Scientific, Gothenburg, Sweden), and 1\% penicillin/streptomycin at $37{ }^{\circ} \mathrm{C}$ in a humid $5 \% \mathrm{CO}_{2}$ incubator. N2a-APP ${ }_{\mathrm{SWE}}$ cells were grown in the same medium in the presence of with $0.8 \%$ geneticin (\#10131-027, ThermoFisher Scientific, Gothenburg, Sweden). 
At $70-80 \%$ cell confluence, cells were transfected with plasmids and Lipofectamine 2000 (\#11668-027, ThermoFisher Scientific, Gothenburg, Sweden) according to the manufacturer's instructions. Controls used in the study (N2a-APP SWE and N2A) were also treated with Lipofectamine 2000 (ThermoFisher Scientific, Gothenburg, Sweden). Fluorescenceactivated cell sorting (FACS) was used to select GFP-transfected cells with plasmids containing either aSyn, Tau, or GFP only. $24 \mathrm{~h}$ after transfection, the cells were trypsinized using Trypsin-EDTA ${ }^{\mathrm{TM}}$ solution (\#15303651, ThermoFisher Scientific, Gothenburg, Sweden), centrifuged for $1 \mathrm{~min}$ at $1000 \times g$, and resuspended in phosphate-buffered saline (PBS) (\#10010-015, Thermo Fisher Scientific, Gothenburg, Sweden). Later, the single-cell suspensions were incubated with a viability dye, Draq7 ${ }^{\mathrm{TM}}$ (\#424001, Biolegend, San Diego, CA, USA), at a dilution of 1:1000 for $10 \mathrm{~min}$ at room temperature in darkness. Thereafter, cells were sorted by a BD FACS Aria III flow cytometer (Santa Cruz Biotechnology, Solna, Sweden) and plated in a $24-w e l l$ plate containing conditioned media ( $50 \%$ conditioned and $50 \%$ new media) at a density of 100,000 cells per well. Data were analyzed using FlowJo ${ }^{\mathrm{TM}}$ software (Becton, Dickinson, and Company, Ashland, MA, USA). All cell lines used in the study were treated using the same protocol and conditions.

\subsection{Synchrotron-Based FTIR Microspectroscopy}

S- $\mu$ FTIR was performed at the SMIS beamline at the synchrotron SOLEIL (L'Orme des Merisiers, 91192 Gif Sur Yvette Cedex, France). For microspectroscopy, the FACS-sorted cells were seeded onto clean 1-mm $\mathrm{CaF}_{2}$ windows (Crystran Ltd., Dorset, UK) and left to adhere on the surface. After two days of growth, cells were fixed in $4 \%$ paraformaldehyde (PFA) solution (Solveco, Rosersberg, Sweden) for $20 \mathrm{~min}$ at room temperature, washed $3 \times 10 \mathrm{~min}$ in PBS, and then rinsed for $10 \mathrm{~min}$ in sterile water.

Single point microscopy was performed using a ThermoFisher Scientific Continuum XL FTIR microscope with a $32 \times$ magnification, 0.65 NA Schwarzschild objective. FTIR spectra were acquired in transition mode with a spectral range between 4000 and $1000 \mathrm{~cm}^{-1}$ at $4 \mathrm{~cm}^{-1}$ spectral resolution with $8 \mu \mathrm{m} \times 8 \mu \mathrm{m}$ aperture dimensions using 256 co-added scans. Background spectra were collected from a clean area of the same $\mathrm{CaF}_{2}$ window. All measurements were made at room temperature.

\subsection{Data Analysis}

Orange software (University of Ljubljana, Slovenia) was used to analyze FTIR spectra after atmospheric compensation using OPUS software (Bruker, Ettlingen, Germany). Derivation of the spectra to the second-order using the Savitzky-Golay method with third polynomial order and seven smoothing points was used to unmask the number of discriminative features and eliminate the baseline contribution. Spectra exhibiting high noise and spectra with strong Mie scattering were eliminated. After baseline correction, all the spectra were normalized. Based on several studies, a consensus has been reached on the assignment of IR components in the Amide I region: $1630-1615 \mathrm{~cm}^{-1}$ is ascribed to the main intermolecular $\beta$-sheet content and the $1697-1690 \mathrm{~cm}^{-1}$ region is ascribed to $\beta$-sheet (weak). The $1655-1638 \mathrm{~cm}^{-1}$ region is defined by random coils, and the $1660-1656 \mathrm{~cm}^{-1}$ region indicates $\alpha$ helices [36,37], as summarized in Table 1 . To analyze protein structures, we used the spectra ratios [40], as summarized in Table 2. A band centered around $1740 \mathrm{~cm}^{-1}$ is mainly assigned to stretching vibration in the carbonyl group of the ester bond $v(\mathrm{C}=\mathrm{O})$ in lipids (triglycerides) [61-63]. As a sign of oxidative stress, we used 1740/1656 ratio [40]. Due to the complex nature of the sample, we only used the relative comparison between samples.

\subsection{A $\beta$ Immunofluorescent Labeling and Confocal Imaging}

Cells were fixed with $4 \%$ PFA for $20 \mathrm{~min}$ at room temperature and later washed $3 \times 5$ min in PBS. The cells were permeabilized with Triton X-100 (Sigma Aldrich, Stockholm, Sweden) in PBS (PBS-T 1\%) for $1 \mathrm{~h}$ and washed $3 \times 5 \mathrm{~min}$ in PBS. Cells were then incubated in blocking solution in 10\% normal donkey serum (NDS) (Millipore, Solna, 
Sweden)) for $1 \mathrm{~h}$ at room temperature and washed $3 \times 5 \mathrm{~min}$ in PBS. The cells were incubated overnight at $4{ }^{\circ} \mathrm{C}$ with primary antibodies: (1:1000) 82E1 (\#10323, IBL America, Minneapolis, MN, USA), 6E10 (\#803013, BioLegend, London, UK), and amyloid fibrils, OC78 (\#ab205341, Abcam, Cambridge, UK). The following day, the cells were washed $3 \times 10$ min in PBS, incubated with secondary antibodies (donkey anti-mouse or anti-rabbit conjugated to Alexa Fluor 555 or 647 (ThermoFisher Scientific, Gothenburg, Sweden)) for 1 $\mathrm{h}$ at room temperature in darkness, washed $3 \times 10 \mathrm{~min}$ PBS and mounted using ProLong ${ }^{\mathrm{TM}}$ Diamond Antifade Mountant (\#P36961, Thermo Fisher Scientific, Gothenburg, Sweden). Digital images were obtained using a Nikon confocal A1RHD laser-scanning microscope using a $60 \times$ oil-immersion objective. Surface rendering and analysis of the fluorescence signal in confocal z-stacks were performed using Imaris 8.0 software (Bitplane Scientific Software, Belfast, UK).

\subsection{Statistical Analysis}

The sample size was determined by power analysis in order to detect statistically significant changes within a $25 \%$ variation of measured responses. One- and two-way ANOVA followed by Bonferroni-corrected two-group posthoc Student $t$-tests were performed using GraphPad Prism8 (GraphPad Software, San Diego, CA, USA). Experiments were replicated with different amyloid- $\beta$-specific antibodies, and 7 to 20 cells were included from two independent experiments.

Supplementary Materials: The following are available online at https:/ /www.mdpi.com/article/10 .3390/ijms22073430/s1, Figure S1: Cell models to study aggregation of amyloid proteins., Figure S2: Figure S1. Cell models to study aggregation of amyloid proteins. Figure S3: Bright-field images of cells after transfection and FACS sorting. Scale bar is $20 \mu \mathrm{m}$. Figure S4: Bright-field images of cells after transfection and FACS sorting. Scale bar is $20 \mu \mathrm{m}$. Figure S5: SDS PAGE followed by western blot analysis with specific antibodies against Tau and $\alpha$ Syn ex-pression after transfection. Figure S6: Particle size was quantified by Imaris (Bitplane Scientific Software, Zurich, Switzerland) after surface rendering in confocal images of the cells immunolabeled with antibodies OC and 82E1. Dashed lines indicate a threshold set for the analysis of rendered surfaces in confocal z-stacks that was used for the fluorescent signal quantification.

Author Contributions: A.P. carried out experiments and wrote the manuscript; A.E. helped with data analysis; Y.Y. helped with FACS of cells; A.B.-S. and S.B. helped with experiments; A.S. and L.T.-G. provided viral constructs; M.G.G., J.-Y.L. and G.K.G. edited the manuscript; O.K. and T.D. designed and helped with the interpretation of the experiments and edited the manuscript. All authors reviewed, edited, and approved the manuscript. All authors have read and agreed to the published version of the manuscript.

Funding: This work was supported by the Swedish Research Council Starting grant 2017-01539, the Swedish Research Council 2019-01551, the Strategic Research Area MultiPark (Multidisciplinary Research focused on Parkinson's disease and related neurodegenerative disorders) at Lund University, Vinnova, HALOS, Crafoord Foundation, Swedish Brain Foundation, Swedish Alzheimer's Foundation, Swedish Parkinsson's Foundation, A.E Berger Foundation, Kockska Foundation, Åke Wiberg, Åhlens, Royal Physiographic Society of Lund.

Institutional Review Board Statement: Not applicable, the study does not involve humans or animals.

Informed Consent Statement: Not applicable.

Data Availability Statement: The data that support the findings of this study can be provided by the corresponding author upon reasonable request.

Acknowledgments: The authors thank Christophe Sandt (SMIS, SOLEIL) for technical support during the spectroscopic measurements.

Conflicts of Interest: The authors declare no conflict of interest. 


\section{References}

1. Amar, F.; Sherman, M.A.; Rush, T.; Larson, M.; Boyle, G.; Chang, L.; Götz, J.; Buisson, A.; Lesné, S.E. The Amyloid- $\beta$ Oligomer A $\beta$ *56 Induces Specific Alterations in Neuronal Signaling That Lead to Tau Phosphorylation and Aggregation. Sci. Signal. 2017, 10, eaal2021. [CrossRef] [PubMed]

2. Gerson, J.E.; Farmer, K.M.; Henson, N.; Castillo-Carranza, D.L.; Carretero Murillo, M.; Sengupta, U.; Barrett, A.; Kayed, R. Tau Oligomers Mediate $\alpha$-Synuclein Toxicity and Can Be Targeted by Immunotherapy. Mol. Neurodegener. 2018, 13, 13. [CrossRef] [PubMed]

3. Kayed, R.; Dettmer, U.; Lesné, S.E. Soluble Endogenous Oligomeric $\alpha$-Synuclein Species in Neurodegenerative Diseases: Expression, Spreading, and Cross-Talk. JPD 2020, 10, 791-818. [CrossRef] [PubMed]

4. Bassil, F.; Brown, H.J.; Pattabhiraman, S.; Iwasyk, J.E.; Maghames, C.M.; Meymand, E.S.; Cox, T.O.; Riddle, D.M.; Zhang, B.; Trojanowski, J.Q.; et al. Amyloid-Beta (A $\beta$ ) Plaques Promote Seeding and Spreading of Alpha-Synuclein and Tau in a Mouse Model of Lewy Body Disorders with A $\beta$ Pathology. Neuron 2020, 105, 260-275.e6. [CrossRef] [PubMed]

5. Colom-Cadena, M.; Gelpi, E.; Charif, S.; Belbin, O.; Blesa, R.; Martí, M.J.; Clarimon, J.; Lleó, A. Confluence of $\alpha$-Synuclein, Tau, and $\beta$-Amyloid Pathologies in Dementia With Lewy Bodies. J. Neuropathol. Exp. Neurol. 2013, 72, 1203-1212. [CrossRef] [PubMed]

6. Bondi, M.W.; Edmonds, E.C.; Salmon, D.P. Alzheimer's Disease: Past, Present, and Future. J. Int. Neuropsychol. Soc. 2017, 23, 818-831. [CrossRef]

7. Hamilton, R.L. Lewy Bodies in Alzheimer's Disease: A Neuropathological Review of 145 Cases Using $\alpha$-Synuclein Immunohistochemistry. Brain Pathol. 2006, 10, 378-384. [CrossRef]

8. Irwin, D.J.; Lee, V.M.-Y.; Trojanowski, J.Q. Parkinson's Disease Dementia: Convergence of $\alpha$-Synuclein, Tau and Amyloid- $\beta$ Pathologies. Nat. Rev. Neurosci. 2013, 14, 626-636. [CrossRef]

9. Robinson, J.L.; Lee, E.B.; Xie, S.X.; Rennert, L.; Suh, E.; Bredenberg, C.; Caswell, C.; Van Deerlin, V.M.; Yan, N.; Yousef, A.; et al. Neurodegenerative Disease Concomitant Proteinopathies Are Prevalent, Age-Related and APOE4-Associated. Brain 2018, 141, 2181-2193. [CrossRef]

10. He, Z.; Guo, J.L.; McBride, J.D.; Narasimhan, S.; Kim, H.; Changolkar, L.; Zhang, B.; Gathagan, R.J.; Yue, C.; Dengler, C.; et al. Amyloid- $\beta$ Plaques Enhance Alzheimer's Brain Tau-Seeded Pathologies by Facilitating Neuritic Plaque Tau Aggregation. Nat. Med. 2018, 24, 29-38. [CrossRef]

11. Hardy, J.; Allsop, D. Amyloid Deposition as the Central Event in the Aetiology of Alzheimer's Disease. Trends Pharmacol. Sci. 1991, 12, 383-388. [CrossRef]

12. Kametani, F.; Hasegawa, M. Reconsideration of Amyloid Hypothesis and Tau Hypothesis in Alzheimer's Disease. Front. Neurosci. 2018, 12, 25. [CrossRef]

13. Schneider, L. A Resurrection of Aducanumab for Alzheimer's Disease. Lancet Neurol. 2020, 19, 111-112. [CrossRef]

14. Panza, F.; Lozupone, M.; Seripa, D.; Imbimbo, B.P. Amyloid- $\beta$ Immunotherapy for Alzheimer Disease: Is It Now a Long Shot? A $\beta$ Immunotherapy Gamble. Ann. Neurol. 2019, 85, 303-315. [CrossRef] [PubMed]

15. Vlassenko, A.G.; Benzinger, T.L.S.; Morris, J.C. PET Amyloid-Beta Imaging in Preclinical Alzheimer's Disease. Biochim. Biophys. Acta BBA Mol. Basis Dis. 2012, 1822, 370-379. [CrossRef]

16. Poduslo, J.F.; Wengenack, T.M.; Curran, G.L.; Wisniewski, T.; Sigurdsson, E.M.; Macura, S.I.; Borowski, B.J.; Jack, C.R. Molecular Targeting of Alzheimer's Amyloid Plaques for Contrast-Enhanced Magnetic Resonance Imaging. Neurobiol. Dis. 2002 , 11, $315-329$. [CrossRef] [PubMed]

17. Dudeffant, C.; Vandesquille, M.; Herbert, K.; Garin, C.M.; Alves, S.; Blanchard, V.; Comoy, E.E.; Petit, F.; Dhenain, M. ContrastEnhanced MR Microscopy of Amyloid Plaques in Five Mouse Models of Amyloidosis and in Human Alzheimer's Disease Brains. Sci. Rep. 2017, 7, 4955. [CrossRef] [PubMed]

18. Takahashi, R.H.; Milner, T.A.; Li, F.; Nam, E.E.; Edgar, M.A.; Yamaguchi, H.; Beal, M.F.; Xu, H.; Greengard, P.; Gouras, G.K. Intraneuronal Alzheimer Abeta42 Accumulates in Multivesicular Bodies and Is Associated with Synaptic Pathology. Am. J. Pathol. 2002, 161, 1869-1879. [CrossRef]

19. Dear, A.J.; Michaels, T.C.T.; Meisl, G.; Klenerman, D.; Wu, S.; Perrett, S.; Linse, S.; Dobson, C.M.; Knowles, T.P.J. Kinetic Diversity of Amyloid Oligomers. Proc. Natl. Acad. Sci. USA 2020, 117, 12087-12094. [CrossRef]

20. Bansal, A.; Schmidt, M.; Rennegarbe, M.; Haupt, C.; Liberta, F.; Stecher, S.; Puscalau-Girtu, I.; Biedermann, A.; Fändrich, M. AA Amyloid Fibrils from Diseased Tissue Are Structurally Different from in Vitro Formed SAA Fibrils. Nat. Commun. 2021, 12, 1013. [CrossRef]

21. Kayed, R. Common Structure of Soluble Amyloid Oligomers Implies Common Mechanism of Pathogenesis. Science 2003, 300, 486-489. [CrossRef]

22. Kayed, R.; Head, E.; Sarsoza, F.; Saing, T.; Cotman, C.W.; Necula, M.; Margol, L.; Wu, J.; Breydo, L.; Thompson, J.L.; et al. Fibril Specific, Conformation Dependent Antibodies Recognize a Generic Epitope Common to Amyloid Fibrils and Fibrillar Oligomers That Is Absent in Prefibrillar Oligomers. Mol. Neurodegener. 2007, 2, 18. [CrossRef] [PubMed]

23. Liu, J.; Costantino, I.; Venugopalan, N.; Fischetti, R.F.; Hyman, B.T.; Frosch, M.P.; Gomez-Isla, T.; Makowski, L. Amyloid Structure Exhibits Polymorphism on Multiple Length Scales in Human Brain Tissue. Sci. Rep. 2016, 6, 33079. [CrossRef]

24. Kollmer, M.; Close, W.; Funk, L.; Rasmussen, J.; Bsoul, A.; Schierhorn, A.; Schmidt, M.; Sigurdson, C.J.; Jucker, M.; Fändrich, M. Cryo-EM Structure and Polymorphism of A $\beta$ Amyloid Fibrils Purified from Alzheimer's Brain Tissue. Nat. Commun. 2019, 10, 4760. [CrossRef] [PubMed] 
25. Klementieva, O.; Sandt, C.; Martinsson, I.; Kansiz, M.; Gouras, G.K.; Borondics, F. Super-Resolution Infrared Imaging of Polymorphic Amyloid Aggregates Directly in Neurons. Adv. Sci. 2020, 7, 1903004. [CrossRef] [PubMed]

26. Baker, M.J.; Trevisan, J.; Bassan, P.; Bhargava, R.; Butler, H.J.; Dorling, K.M.; Fielden, P.R.; Fogarty, S.W.; Fullwood, N.J.; Heys, K.A.; et al. Using Fourier Transform IR Spectroscopy to Analyze Biological Materials. Nat. Protoc. 2014, 9, 1771-1791. [CrossRef]

27. Bombalska, A.; Mularczyk-Oliwa, M.; Kwaśny, M.; Włodarski, M.; Kaliszewski, M.; Kopczyński, K.; Szpakowska, M.; Trafny, E.A. Classification of the Biological Material with Use of FTIR Spectroscopy and Statistical Analysis. Spectrochim. Acta Part A Mol. Biomol. Spectrosc. 2011, 78, 1221-1226. [CrossRef] [PubMed]

28. Prentice, B.M.; Caprioli, R.M.; Vuiblet, V. Label-Free Molecular Imaging of the Kidney. Kidney Int. 2017, 92, 580-598. [CrossRef]

29. Klementieva, O.; Willén, K.; Martinsson, I.; Israelsson, B.; Engdahl, A.; Cladera, J.; Uvdal, P.; Gouras, G.K. Pre-Plaque Conformational Changes in Alzheimer's Disease-Linked A $\beta$ and APP. Nat. Commun. 2017, 8, 14726. [CrossRef]

30. Miller, L.M.; Dumas, P. From Structure to Cellular Mechanism with Infrared Microspectroscopy. Curr. Opin. Struct. Biol. 2010, 20, 649-656. [CrossRef]

31. Diem, M.; Romeo, M.; Boydston-White, S.; Miljković, M.; Matthäus, C. A Decade of Vibrational Micro-Spectroscopy of Human Cells and Tissue (1994-2004). Analyst 2004, 129, 880-885. [CrossRef] [PubMed]

32. Holman, H.-Y.N.; Martin, M.C.; McKinney, W.R. Synchrotron-Based FTIR Spectromicroscopy: Cytotoxicity and Heating Considerations. J. Biol. Phys. 2003, 29, 275-286. [CrossRef] [PubMed]

33. DeFlores, L.P.; Ganim, Z.; Nicodemus, R.A.; Tokmakoff, A. Amide I'-II' 2D IR Spectroscopy Provides Enhanced Protein Secondary Structural Sensitivity. J. Am. Chem. Soc. 2009, 131, 3385-3391. [CrossRef]

34. Jackson, M.; Mantsch, H.H. The Use and Misuse of FTIR Spectroscopy in the Determination of Protein Structure. Crit. Rev. Biochem. Mol. Biol. 1995, 30, 95-120. [CrossRef]

35. Byler, D.M.; Susi, H. Examination of the Secondary Structure of Proteins by Deconvolved FTIR Spectra. Biopolymers 1986, 25, 469-487. [CrossRef] [PubMed]

36. Barth, A. Infrared Spectroscopy of Proteins. Biochim. Biophys. Acta BBA Bioenerg. 2007, 1767, 1073-1101. [CrossRef]

37. Cerf, E.; Sarroukh, R.; Tamamizu-Kato, S.; Breydo, L.; Derclaye, S.; Dufrêne, Y.F.; Narayanaswami, V.; Goormaghtigh, E.; Ruysschaert, J.-M.; Raussens, V. Antiparallel $\beta$-Sheet: A Signature Structure of the Oligomeric Amyloid $\beta$-Peptide. Biochem. J. 2009, 421, 415-423. [CrossRef]

38. Roeters, S.J.; Iyer, A.; Pletikapić, G.; Kogan, V.; Subramaniam, V.; Woutersen, S. Evidence for Intramolecular Antiparallel BetaSheet Structure in Alpha-Synuclein Fibrils from a Combination of Two-Dimensional Infrared Spectroscopy and Atomic Force Microscopy. Sci. Rep. 2017, 7, 41051. [CrossRef]

39. Benseny-Cases, N.; Klementieva, O.; Cladera, J. In vitro Oligomerization and Fibrillogenesis of Amyloid-beta Peptides. In Protein Aggregation and Fibrillogenesis in Cerebral and Systemic Amyloid Disease; Harris, J.R., Ed.; Springer: Dordrecht, The Netherlands, 2012; Volume 65, pp. 53-74. ISBN 978-94-007-5415-7.

40. Benseny-Cases, N.; Klementieva, O.; Cotte, M.; Ferrer, I.; Cladera, J. Microspectroscopy (MFTIR) Reveals Co-Localization of Lipid Oxidation and Amyloid Plaques in Human Alzheimer Disease Brains. Anal. Chem. 2014, 86, 12047-12054. [CrossRef]

41. Olsson, T.T.; Klementieva, O.; Gouras, G.K. Prion-like Seeding and Nucleation of Intracellular Amyloid- $\beta$. Neurobiol. Dis. 2018, 113, 1-10. [CrossRef]

42. Mullan, M.; Crawford, F.; Axelman, K.; Houlden, H.; Lilius, L.; Winblad, B.; Lannfelt, L. A Pathogenic Mutation for Probable Alzheimer's Disease in the APP Gene at the N-Terminus of $\beta$-Amyloid. Nat. Genet. 1992, 1, 345-347. [CrossRef]

43. Haass, C.; Lemere, C.A.; Capell, A.; Citron, M.; Seubert, P.; Schenk, D.; Lannfelt, L.; Selkoe, D.J. The Swedish Mutation Causes Early-Onset Alzheimer's Disease by $\beta$-Secretase Cleavage within the Secretory Pathway. Nat. Med. 1995, 1, 1291-1296. [CrossRef]

44. Aho, L.; Pikkarainen, M.; Hiltunen, M.; Leinonen, V.; Alafuzoff, I. Immunohistochemical Visualization of Amyloid- $\beta$ Protein Precursor and Amyloid- $\beta$ in Extra- and Intracellular Compartments in the Human Brain. JAD 2010, 20, 1015-1028. [CrossRef]

45. Hatami, A.; Albay, R.; Monjazeb, S.; Milton, S.; Glabe, C. Monoclonal Antibodies against A $\beta 42$ Fibrils Distinguish Multiple Aggregation State Polymorphisms in Vitro and in Alzheimer Disease Brain. J. Biol. Chem. 2014, 289, 32131-32143. [CrossRef]

46. Marcelli, A.; Cricenti, A.; Kwiatek, W.M.; Petibois, C. Biological Applications of Synchrotron Radiation Infrared Spectromicroscopy. Biotechnol. Adv. 2012, 30, 1390-1404. [CrossRef]

47. Sun, Y.; Hou, S.; Zhao, K.; Long, H.; Liu, Z.; Gao, J.; Zhang, Y.; Su, X.-D.; Li, D.; Liu, C. Cryo-EM Structure of Full-Length $\alpha$-Synuclein Amyloid Fibril with Parkinson's Disease Familial A53T Mutation. Cell Res. 2020, 30, 360-362. [CrossRef]

48. Linse, S.; Scheidt, T.; Bernfur, K.; Vendruscolo, M.; Dobson, C.M.; Cohen, S.I.A.; Sileikis, E.; Lundqvist, M.; Qian, F.; O’Malley, T.; et al. Kinetic Fingerprints Differentiate the Mechanisms of Action of Anti-A $\beta$ Antibodies. Nat. Struct. Mol. Biol. 2020, 27, 1125-1133. [CrossRef] [PubMed]

49. Grimaldi, P.; Di Giambattista, L.; Giordani, S.; Udroiu, I.; Pozzi, D.; Gaudenzi, S.; Bedini, A.; Giliberti, C.; Palomba, R.; Congiu Castellano, A. Ultrasound-Mediated Structural Changes in Cells Revealed by FTIR Spectroscopy: A Contribution to the Optimization of Gene and Drug Delivery. Spectrochim. Acta Part A Mol. Biomol. Spectrosc. 2011, 84, 74-85. [CrossRef]

50. Liu, H.; Su, Q.; Wu, Q.; Fang, W.; Yang, D.; Zheng, W.; Wang, X. FTIR Spectroscopic Study on Apoptosis of Lung Cancer Cell Line A549 Induced by Arsenic Trioxide. Infrared Phys. Technol. 2018, 93, 340-345. [CrossRef]

51. Miller, L.M.; Bourassa, M.W.; Smith, R.J. FTIR Spectroscopic Imaging of Protein Aggregation in Living Cells. Biochim. Biophys. Acta BBA Biomembr. 2013, 1828, 2339-2346. [CrossRef] 
52. Sorrentino, Z.A.; Goodwin, M.S.; Riffe, C.J.; Dhillon, J.-K.S.; Xia, Y.; Gorion, K.-M.; Vijayaraghavan, N.; McFarland, K.N.; Golbe, L.I.; Yachnis, A.T.; et al. Unique $\alpha$-Synuclein Pathology within the Amygdala in Lewy Body Dementia: Implications for Disease Initiation and Progression. Acta Neuropathol. Commun. 2019, 7, 142. [CrossRef]

53. Guo, T.; Noble, W.; Hanger, D.P. Roles of Tau Protein in Health and Disease. Acta Neuropathol. 2017, 133, 665-704. [CrossRef]

54. Spadea, A.; Denbigh, J.; Lawrence, M.J.; Kansiz, M.; Gardner, P. Analysis of Fixed and Live Single Cells Using Optical Photothermal Infrared with Concomitant Raman Spectroscopy. Anal. Chem. 2021. [CrossRef]

55. Peng, C.; Gathagan, R.J.; Covell, D.J.; Medellin, C.; Stieber, A.; Robinson, J.L.; Zhang, B.; Pitkin, R.M.; Olufemi, M.F.; Luk, K.C.; et al. Cellular Milieu Imparts Distinct Pathological $\alpha$-Synuclein Strains in $\alpha$-Synucleinopathies. Nature 2018, 557, 558-563. [CrossRef]

56. Khan, S.S.; LaCroix, M.; Boyle, G.; Sherman, M.A.; Brown, J.L.; Amar, F.; Aldaco, J.; Lee, M.K.; Bloom, G.S.; Lesné, S.E. Bidirectional Modulation of Alzheimer Phenotype by Alpha-Synuclein in Mice and Primary Neurons. Acta Neuropathol. 2018, 136, 589-605. [CrossRef]

57. Boza-Serrano, A.; Ruiz, R.; Sanchez-Varo, R.; García-Revilla, J.; Yang, Y.; Jimenez-Ferrer, I.; Paulus, A.; Wennström, M.; Vilalta, A.; Allendorf, D.; et al. Galectin-3, a Novel Endogenous TREM2 Ligand, Detrimentally Regulates Inflammatory Response in Alzheimer's Disease. Acta Neuropathol. 2019, 138, 251-273. [CrossRef]

58. Honcharenko, D.; Juneja, A.; Roshan, F.; Maity, J.; Galán-Acosta, L.; Biverstål, H.; Hjorth, E.; Johansson, J.; Fisahn, A.; Nilsson, L.; et al. Amyloid- $\beta$ Peptide Targeting Peptidomimetics for Prevention of Neurotoxicity. ACS Chem. Neurosci. 2019, 10, $1462-1477$. [CrossRef]

59. Szepesi, Z.; Manouchehrian, O.; Bachiller, S.; Deierborg, T. Bidirectional Microglia-Neuron Communication in Health and Disease. Front. Cell. Neurosci. 2018, 12, 323. [CrossRef]

60. Martinsson, I.; Capetillo-Zarate, E.; Faideau, M.; Willén, K.; Esteras, N.; Frykman, S.; Tjernberg, L.O.; Gouras, G.K. APP Depletion Alters Selective Pre- and Post-Synaptic Proteins. Mol. Cell. Neurosci. 2019, 95, 86-95. [CrossRef]

61. Voortman, G.; Gerrits, J.; Altavilla, M.; Henning, M.; van Bergeijk, L.; Hessels, J. Quantitative Determination of Faecal Fatty Acids and Triglycerides by Fourier Transform Infrared Analysis with a Sodium Chloride Transmission Flow Cell. Clin. Chem. Lab. Med. 2002, 40. [CrossRef]

62. Nara, M.; Okazaki, M.; Kagi, H. Infrared Study of Human Serum Very-Low-Density and Low-Density Lipoproteins. Implication of Esterified Lipid C-O Stretching Bands for Characterizing Lipoproteins. Chem. Phys. Lipids 2002, 117, 1-6. [CrossRef]

63. Petibois, C.; Déléris, G. Analysis and Monitoring of Oxidative Stress in Exercise and Training by FTIR Spectrometry. Int. J. Sports Physiol. Perform. 2008, 3, 119-130. [CrossRef] [PubMed] 